\title{
Bartonella henselae infection presenting as cervical spine osteomyelitis: case report
}

\author{
Syed Hassan A. Akbari, MD, ${ }^{1}$ Christine E. Averill, BA, ${ }^{1}$ Jarod L. Roland, MD, ${ }^{1}$ \\ Rachel Orscheln, MD, ${ }^{2}$ and Jennifer Strahle, MD'
}

\begin{abstract}
Departments of ${ }^{1}$ Neurological Surgery and 2 Pediatrics, St. Louis Children's Hospital, Washington University in St. Louis School of Medicine, St. Louis, Missouri
\end{abstract}

\begin{abstract}
Bartonella henselae is a gram-negative bacillus implicated in cat-scratch disease. Cat-scratch disease is usually selflimiting and results in local lymphadenopathy. In rare circumstances, patients may develop endocarditis, neuroretinitis, or osteomyelitis. Osteomyelitis of the cervical spine is exceedingly rare, especially in the pediatric population, and to date there have been only 4 previously reported cases of cervical spine osteomyelitis caused by $B$. henselae, all of which were treated surgically. In this article, the authors report the case of a 7-year-old boy who presented with neck swelling and was found to have a C2-4 paravertebral $B$. henselae abscess with osteomyelitis of C-3 and epidural extension. To the authors' knowledge, this represents the first case in the literature of a cervical spine $B$. henselae infection managed conservatively.
\end{abstract}

https://thejns.org/doi/abs/10.3171/2018.2.PEDS17600

KEYWORDS Bartonella henselae; osteomyelitis; lymphadenopathy; cat-scratch disease; cervical spine; infection

$\mathrm{B}$ artonella henselae is a gram-negative bacillus proteobacterium implicated in cat-scratch disease (CSD), endocarditis, bacillary angiomatosis, and peliosis hepatitis. ${ }^{20,26}$ Osteomyelitis of the cervical spine is exceedingly rare in the pediatric population, especially secondary to CSD. There are few cases in the literature, with all reported cases treated surgically. $25,32,34,35$ This case report describes a 7-year-old boy who presented with a painless swelling of the right neck. Imaging revealed a C2-4 paraspinal abscess with lytic destruction of the right C-3 lateral mass and epidural extension causing mass effect on the spinal cord that was found to be caused by CSD. The infection was successfully treated with antibiotics. To our knowledge, this is the fourth case of cervical spine osteomyelitis described in the literature and the first to be managed conservatively.

\section{Case Report}

A 7-year-old boy presented to the emergency department with a right-sided neck mass. The patient reported an enlarging mass in his right neck growing over the prior month. The patient underwent an ultrasound and CT scan (Fig. 1) before arriving to the emergency department. There was no associated pain, though there was discomfort on neck rotation to the right and with extension. There were no fevers, chills, nausea, vomiting, or difficulty swallowing or breathing. The patient was not on any medications. On examination, the patient had an enlarged mass on the right side, approximately $2.5 \times 2.5 \mathrm{~cm}$ without tenderness, warmth, drainage, or erythema. The mass was firm and mobile. The patient had a normal white blood cell (WBC) count of $7.8 \times 10^{9} / \mathrm{L}$, platelet count of $504 \times$ $10 \% / \mathrm{L}$, and elevated erythrocyte sedimentation rate (ESR) of $36.0 \mathrm{~mm} / \mathrm{hr}$. The patient was immunocompetent. The outside hospital ultrasound demonstrated a $2.8 \times 1.5-\mathrm{cm}$ hypoechoic lesion, and the contrast-enhanced CT scan revealed a $2.0 \times 2.5-\mathrm{cm}$ rim-enhancing hypodense mass in the right posterior neck abutting the right $\mathrm{C}-3$ lateral mass with lytic changes. The patient was admitted to the floor and underwent an MRI scan, which demonstrated a $2.5 \times$ $2.5 \times 3.0-\mathrm{cm}$ peripherally enhancing mass from the level

ABBREVIATIONS CRP = C-reactive protein; $\mathrm{CSD}=$ cat-scratch disease; $\mathrm{ESR}=$ erythrocyte sedimentation rate; $\mathrm{PCR}=$ polymerase chain reaction; $\mathrm{WBC}=$ white blood cell. SUBMITTED October 28, 2017. ACCEPTED February 27, 2018.

INCLUDE WHEN CITING Published online May 25, 2018; DOI: 10.3171/2018.2.PEDS17600. 

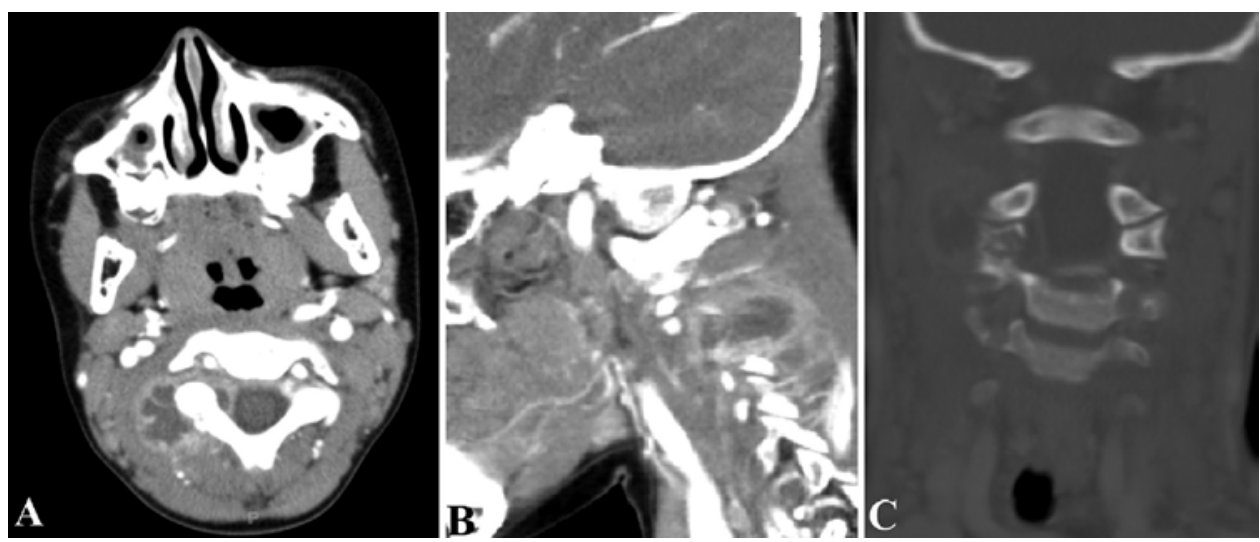

FIG. 1. A: Axial contrast-enhanced CT image revealing a $2.0 \times 2.5-\mathrm{cm}$ rim-enhancing lesion in the right posterior triangle of the neck at the level of C-3 abutting the lateral mass with epidural extension. B: Sagittal contrast-enhanced CT image showing a 2.5 $\times 3.0-\mathrm{cm}$ rim-enhancing lesion in the right posterior triangle of the neck. C: Coronal bone-window CT image revealing a rightsided hypodense neck mass with lytic changes affecting the right C-3 lateral mass.

of $\mathrm{C}-2$ to the level of C-4 with epidural extension at C-3, resulting in mild mass effect on the spinal cord in addition to lytic changes to the right lateral mass of C-3 (Fig. 2). Additionally noted was significant soft tissue edema. Of note, the infection did not appear to involve the disc space. CT-guided fine-needle aspiration and core needle biopsies of the soft tissue lesion were performed and showed necrotizing granulomas without organisms. Cytological
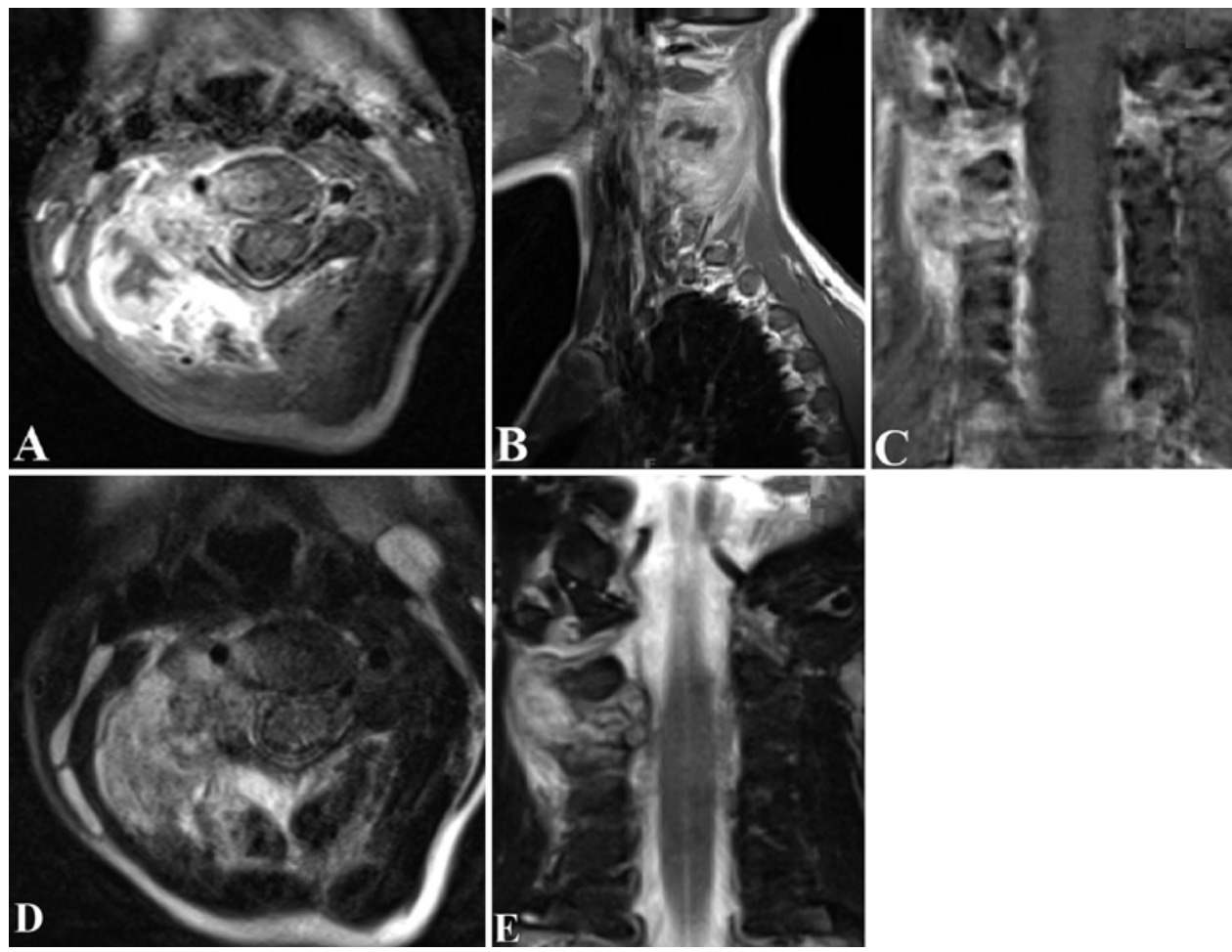

FIG. 2. A: Axial contrast-enhanced T1-weighted MR image showing a $2.5 \times 2.5-\mathrm{cm}$ peripherally enhancing mass and a centrally necrotic core with enhancement and bony destruction through the right C-3 lateral mass with epidural extension. Also noted is enhancement through the soft tissues of the right posterior neck. B: Sagittal contrast-enhanced T1-weighted MR image revealing a $2.5 \times 3.0-\mathrm{cm}$ peripherally enhancing mass in the right posterior neck with significant paraspinal soft tissue enhancement and a central necrotic core. C: Coronal contrast-enhanced T1-weighted MR image demonstrating a $2.5 \times 3.0-\mathrm{cm}$ peripherally enhancing mass with epidural extension and involving the lateral mass of $\mathrm{C}-3$. The lesion extends from the $\mathrm{C}-2$ level to the $\mathrm{C}-4$ level. D: Axial T2-weighted MR image revealing significant soft tissue edema in the right posterior triangle of the neck. E: Coronal T2-weighted MR image showing significant soft tissue edema in the right posterior neck in addition to lytic changes in the right lateral mass of C-3. 

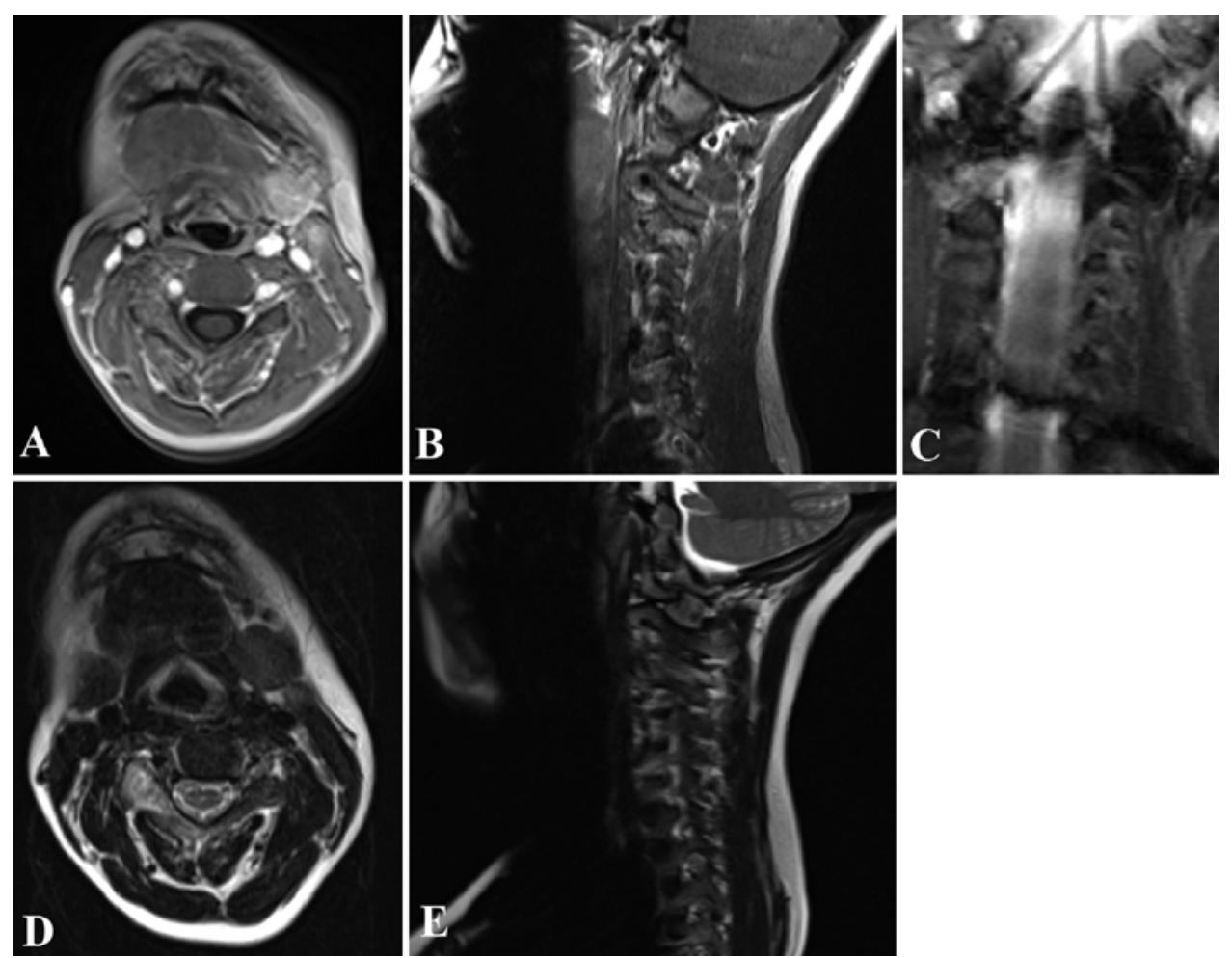

FIG. 3. A-C: Axial (A), sagittal (B), and coronal (C) contrast-enhanced T1-weighted MR images obtained at 1-year follow-up visit revealing resolution of the enhancing mass in the right posterior neck. D and E: Axial (D) and sagittal (E) T2-weighted MR images obtained at 1-year follow-up visit revealing continued reduction in soft tissue edema.

evaluation was nondiagnostic. Fungal, acid-fast bacillus, aerobic, and anaerobic cultures were negative. The patient's vitamin D and calcium levels were within normal limits. He was discharged on oral amoxicillin clavulanate (Augmentin) while awaiting culture results after discussion with the infectious disease service. Prior to discharge he was fitted with a Miami J collar, given the lytic lateral mass at C-3. Cervical spine radiographs showed normal alignment.

Serum testing for $B$. henselae antibodies showed a highly elevated IgG antibody titer ( $\geq 1: 1024)$ and a normal IgM titer $(<1: 20)$. Of note, the patient later revealed exposure to a 6-month-old kitten who had scratched the patient on the chest. A 6-week course of azithromycin and rifampin therapy was initiated. The patient returned for a 1-month follow-up visit at which he reported no neck pain. Follow-up imaging revealed a reduction in the size of his lesion. His WBC count was $5.5 \times 10^{9} / \mathrm{L}$, his platelet count was $323 \times 10^{9} / \mathrm{L}$, his C-reactive protein (CRP) level was $0.8 \mathrm{mg} / \mathrm{L}$ (reference range $0-10 \mathrm{mg} / \mathrm{L}$ ), and his ESR had decreased to $11.0 \mathrm{~mm} / \mathrm{hr}$ (reference range $0-20 \mathrm{~mm} / \mathrm{hr}$ ). At his 6-week follow-up visit, the patient had further improvement of his symptoms and imaging findings, and his collar use was discontinued. At 1 year's follow-up, the patient continued to do well. An MRI study obtained at that time (Fig. 3) showed resolution of the enhancing lesion, while cervical spine radiographs revealed normal alignment without dynamic instability.

\section{Discussion}

Bartonella henselae is an aerobic gram-negative bacillus implicated in CSD, endocarditis, bacteremia, and peliosis hepatitis. Interestingly, Bartonella bacteremia in natural hosts can be asymptomatic.,20 In the present patient, we hypothesize that $B$. henselae was likely present in the patient's cat, which transmitted the disease to the patient via a scratch.

Approximately 24,000 cases of CSD occur each year, with an incidence of 9.3/10,00022 and most cases occurring in individuals under age 18 years..$^{10,16} \mathrm{CSD}$ in immunocompetent patients usually presents as a local lymphadenopathy or regional infection. ${ }^{11,20,27}$ In immunocompromised hosts, however, $B$. henselae can lead to bacteremia, bacillary peliosis, angiomatosis, or endocarditis. , $^{8,11,20}$

CSD can be diagnosed via serological tests such as the indirect immunofluorescence assay (IFA), ${ }^{12,28}$ enzymelinked immunosorbent assay (ELISA), ${ }^{4,5,22}$ immunofluorescence, ${ }^{14,23,31,36}$ and polymerase chain reaction (PCR). ${ }^{3,6}$ The organism rarely can be visualized by microscopy using silver stain. Serological tests detect anti-Bartonella IgM or IgG. Diagnosis of CSD was confirmed by serological testing with positive $\operatorname{IgG}$ titers in the present case.

Osteolytic lesions in CSD are rare. One study of 1200 cases of CSD found a lytic lesion rate of $0.17 \%$, with the vertebral column commonly affected. ${ }^{10} \mathrm{~A}$ recent review of 47 cases revealed the vertebral column to be involved in $42 \%$ of cases in both adult and pediatric patients. ${ }^{15}$ Lytic 
TABLE 1. Reported cases of cervical spine osteomyelitis secondary to $B$. henselae infection

\begin{tabular}{|c|c|c|c|c|c|c|c|c|c|c|c|}
\hline $\begin{array}{l}\text { Authors } \\
\& \text { Year }\end{array}$ & $\begin{array}{l}\text { Age } \\
\text { (yrs), } \\
\text { Sex }\end{array}$ & Symptom & Fever & $\begin{array}{c}\text { WBCl } \\
\text { ESR/CRP } \\
\text { Elevation }\end{array}$ & Level & Diagnosis & $\begin{array}{c}\text { Epidural } \\
\text { Involvement }\end{array}$ & Surgery & $\begin{array}{l}\text { Antibiotic } \\
\text { Duration }\end{array}$ & $\begin{array}{c}\text { Recurrence } \\
\text { Treatment }\end{array}$ & $\begin{array}{l}\text { Follow- } \\
\text { Up }\end{array}$ \\
\hline $\begin{array}{r}\text { Woestyn et } \\
\text { al., } 2003\end{array}$ & $62, F$ & $\begin{array}{l}\text { Neck pain, } \\
\text { paresthesia }\end{array}$ & Y & $\mathrm{Y} / \mathrm{NR} / \mathrm{Y}$ & C5-6 & $\begin{array}{l}\lg G+ \\
\text { PCR + }\end{array}$ & NR & $\begin{array}{c}\text { C5-6 discectomy } \\
\text { \& arthrodesis }\end{array}$ & $6 \mathrm{mos}$ & Y, drainage & $9 \mathrm{mos}$ \\
\hline $\begin{array}{l}\text { Vermeulen et } \\
\text { al., } 2006\end{array}$ & $9, F$ & $\begin{array}{l}\text { Neck pain, } \\
\text { torticollis, } \\
\text { delayed right } \\
\text { arm paresis }\end{array}$ & $Y$ & $\mathrm{Y} / \mathrm{Y} / \mathrm{Y}$ & C4-6 & $\begin{array}{l}\lg M+ \\
\lg G+ \\
\text { PCR }+\end{array}$ & $\mathrm{N}$ & $\begin{array}{l}\text { Anterior open } \\
\text { biopsy \& drain- } \\
\text { age }\end{array}$ & 3 wks & $\mathrm{N}$ & $3 \mathrm{mos}$ \\
\hline $\begin{array}{l}\text { Tasher et al., } \\
2009\end{array}$ & $5, M$ & $\begin{array}{l}\text { Neck pain, } \\
\text { torticollis }\end{array}$ & $Y$ & $\mathrm{Y} / \mathrm{Y} / \mathrm{N}$ & $\begin{array}{l}\text { Skull base } \\
\text { to C-6 }\end{array}$ & $\lg M+$ & Y & $\begin{array}{l}\text { C3-5 laminecto- } \\
\text { my w/ abscess } \\
\text { drainage }\end{array}$ & 10 wks & $\mathrm{N}$ & 9 wks \\
\hline $\begin{array}{l}\text { Mirouse et } \\
\text { al., } 2015\end{array}$ & $14, \mathrm{M}$ & $\begin{array}{l}\text { Neck pain, } \\
\text { torticollis }\end{array}$ & $Y$ & $\mathrm{Y} / \mathrm{NR} / \mathrm{Y}$ & C-2 & $\begin{array}{l}\text { Serology } \\
+\end{array}$ & $\mathrm{N}$ & $\begin{array}{l}\text { Traction, surgical } \\
\text { drainage }\end{array}$ & 10 wks & $\mathrm{N}$ & $3 \mathrm{mos}$ \\
\hline Present case & $7, M$ & Neck mass & $\mathrm{N}$ & N/Y/NT & C2-4 & $\lg G+$ & Y & None, collar & 6 wks & $\mathrm{N}$ & $12 \mathrm{mos}$ \\
\hline
\end{tabular}

$\mathrm{N}=$ no (not present); NR = not reported; $\mathrm{NT}=$ not tested; $\mathrm{Y}=$ yes (present); + = positive.

lesions usually develop in the context of a systemic Bartonella infection and usually have a good prognosis. ${ }^{13}$

Cat-scratch disease osteomyelitis and discitis are most often seen in the thoracolumbar vertebrae and pelvic girdle. 1,2,9,17,18,21,29,30,33 Osteomyelitis specific to the cervical spine, however, is exceedingly rare, especially when secondary to CSD. ${ }^{34}$

Plain radiographs may reveal lytic lesions with occasional sclerosis or periosteal reaction with focal lucency. ${ }^{24,29} \mathrm{CT}$ will reveal osseous lucencies and destructive changes of involved bone, with MRI revealing bone marrow and soft tissue involvement with contrast enhancement and increased T2 signal. ${ }^{2,29}$ Our patient presented with radiographic assessments consistent with these prior reports.

\section{Literature Review}

To our knowledge, there have been only 4 previously reported cases of cervical spine osteomyelitis caused by CSD, all of which required surgical intervention (Table 1). In 2003, Woestyn and colleagues described cervical spine tumefaction in a 62-year-old woman. ${ }^{35}$ Their patient presented with a 2-week history of pain in the cervical spine with bilateral paresthesias, intermittent fevers, and night sweats. She owned approximately 20 cats. Her CRP level was elevated at $12.3 \mathrm{mg} / \mathrm{L}$, and her WBC count was $14.8 \times 10^{9} / \mathrm{L}$. An ultrasound examination revealed necrotic lymphadenopathy, and a CT scan revealed a paravertebral mass with involvement of the C-5 and C- 6 vertebrae. A biopsy showed necrotizing granulomatous inflammation, and a serological test revealed a positive $\operatorname{IgG} B$. henselae titer. The patient underwent C-5 and C-6 discectomy and arthrodesis in a delayed fashion. Purulence was noted as well as destruction of C-6. PCR confirmed the presence of $B$. henselae. The patient was treated with 3 weeks of intravenous ofloxacin and clindamycin with a favorable response and continued with 2 months of oral ofloxacin and 6 months of clarithromycin. She returned 2 months postoperatively for new tumefaction of the left cervical area with serological testing revealing $\operatorname{IgM}$ and $\operatorname{IgG}$ against $B$. henselae. The collection was drained, and repeat MRI at 9 months after surgery revealed no further signs of infection.

In 2006, Vermeulen et al. reported the first case of a pediatric CSD cervical osteomyelitis. ${ }^{34}$ They described the case of a 9-year-old girl who presented with 3 days of fever and neck pain with torticollis. The patient's ESR and CRP level were elevated at $104 \mathrm{~mm} / \mathrm{hr}$ and $72 \mathrm{mg} / \mathrm{L}$, respectively. The WBC count was mildly elevated at 12.5 $\times 10^{9} / \mathrm{L}$. Three days later, the patient developed paresis of the proximal right arm with areflexia. An MRI revealed C4-6 osteomyelitis with a paravertebral mass. An anterior cervical approach was taken to perform an open biopsy and drainage of the abscess. Tests of the purulent material were negative for organisms. The patient was treated with intravenous amoxicillin clavulanate for 3 weeks and was provided a rigid cervical collar. She was eventually discharged with improvement in her symptoms except right arm paresis. Three weeks after discharge, it was revealed that the patient's family had recently bought a young kitten prior to the patient's episode. Immunofluorescence showed positive IgM and IgG titers against $B$. henselae. The initial surgical specimen was then tested with PCR, which was positive for $B$. henselae. Repeat imaging at 6 weeks revealed no abnormality, and the patient had returned to her neurological baseline by 3 months.

In 2009, Tasher and colleagues reported on a 5-yearold boy who presented to the emergency department with painful torticollis after a week of treatment for presumed tonsillitis. ${ }^{32}$ Upon examination he was found to have a low-grade fever and enlarged tonsils with palpable lymph nodes. His social history was significant for a kitten in the household. The patient was admitted to the floor. Blood cultures were negative and serological tests for $B$. henselae were positive for IgM. The patient's WBC count was 14.6 $\times 10^{3} / \mathrm{ml}$, his ESR was $65 \mathrm{~mm} / \mathrm{hr}$, and his CRP level was $3.1 \mathrm{mg} / \mathrm{dl}$. MRI demonstrated an anterior spinal epidural abscess from C-1 to C-6 with cervical cord compression. 
A follow-up MRI study performed 1 week later revealed significant cord compression by an increasing epidural abscess. The patient underwent laminectomies at C3-5 with drainage of the abscess. PCR was positive for $B$. henselae. He did well and completed a 10-week course of antibiotics. A follow-up MRI study performed at 6 weeks after surgery showed resolution of the abscess and at 9 weeks' follow-up, his CRP level was $<0.1 \mathrm{mg} / \mathrm{dl}$.

In 2015, Mirouse et al. described a 14-year-old boy who developed cervical spine osteoarthritis with osteolysis of the lateral mass of C-2 secondary to $B$. henselae infection. ${ }^{25}$ The patient presented to his family physician after experiencing a cat scratch on the fifth digit associated with neck pain. The patient was treated with azithromycin, but eventually developed cervicalgia, torticollis, fever, and lymphadenopathy, with a WBC count of $7900 / \mathrm{mm}^{3}$ and CRP level of $111 \mathrm{mg} / \mathrm{L}$. A CT scan showed a joint effusion and osteolysis of the lateral mass of C-2. MRI showed no signs of epidural extension. The patient was immobilized in cervical traction and 48 hours later underwent surgical drainage via a posterior approach. Purulence was noted at the right $\mathrm{C} 1-2$ facet joint with $50 \%$ osteolysis of the lateral mass of C-2. Treatment with amoxicillin-clavulanic acid, ciprofloxacin, and gentamicin was initiated postoperatively, and the patient was placed in a halo orthosis for a total of 3 months. Tests were positive for $B$. henselae. The patient underwent a total of 12 weeks of antibiotic therapy.

Our case has multiple unique features that distinguish it from previously reported cases of cervical spine osteomyelitis caused by CSD. This is the first reported case to be treated conservatively. Our patient did not have significant neck pain or torticollis on presentation and did not have a neurological deficit. Additionally, our patient remained afebrile. Most significantly, our patient was able to be treated conservatively with long-term antibiotic therapy. This case emphasizes including CSD in the differential diagnosis for cervical lytic lesions associated with lymphadenopathy even in the absence of neurological deficit or significant pain. Moreover, taking an adequate history, including queries regarding household pets, in addition to performing a diagnostic workup with the proper serological tests is critical to reaching the diagnosis. Additionally, our patient's osteomyelitis appears to have avoided the disc space. Most often, spine infection presents as osteomyelitis-discitis. The current case highlights the fact that CSD infection may present as a culture-negative spinal infection that does not involve the disc space. It also highlights the fact that in certain situations, surgical intervention may not be necessary. Instead, long-term antibiotic therapy with follow-up imaging may be a successful treatment strategy for patients with CSD of the cervical spine.

\section{Conclusions}

Cat-scratch disease can have myriad clinical presentations and must be included in the differential diagnosis of a swollen neck mass causing osteomyelitis of the cervical spine. Biopsy specimens will likely show granulomatous inflammation, and serological testing should reveal antiBartonella antibodies. Cultures are often unrevealing in $B$. henselae osteomyelitis. WBC counts may not be ele- vated in $B$. henselae osteomyelitis, while CRP levels may be elevated and useful in assessing treatment response. In the setting of minimal neck pain and no neurological deficit, these lesions can be treated conservatively with long-term antibiotic therapy and should be followed with serial imaging to ensure treatment effect and monitor for recurrence.

\section{References}

1. Abdel-Haq N, Abuhammour W, Al-Tatari H, Asmar B: Disseminated cat scratch disease with vertebral osteomyelitis and epidural abscess. South Med J 98:1142-1145, 2005

2. Al-Rahawan MM, Gray BM, Mitchell CS, Smith SD: Thoracic vertebral osteomyelitis with paraspinous mass and intraspinal extension: an atypical presentation of cat-scratch disease. Pediatr Radiol 42:116-119, 2012

3. Anderson B, Sims K, Regnery R, Robinson L, Schmidt MJ, Goral S, et al: Detection of Rochalimaea henselae DNA in specimens from cat scratch disease patients by PCR. J Clin Microbiol 32:942-948, 1994

4. Barka NE, Hadfield T, Patnaik M, Schwartzman WA, Peter JB: EIA for detection of Rochalimaea henselae-reactive IgG, IgM, and IgA antibodies in patients with suspected catscratch disease. J Infect Dis 167:1503-1504, 1993

5. Bergmans AM, Peeters MF, Schellekens JF, Vos MC, Sabbe LJ, Ossewaarde JM, et al: Pitfalls and fallacies of cat scratch disease serology: evaluation of Bartonella henselae-based indirect fluorescence assay and enzyme-linked immunoassay. J Clin Microbiol 35:1931-1937, 1997

6. Birtles RJ: Differentiation of Bartonella species using restriction endonuclease analysis of PCR-amplified 16S rRNA genes. FEMS Microbiol Lett 129:261-265, 1995

7. Brock TD: Robert Koch, a Life in Medicine and Bacteriology. Washington, DC: ASM Press, 1999

8. Brouqui P, Raoult D: Endocarditis due to rare and fastidious bacteria. Clin Microbiol Rev 14:177-207, 2001

9. Brunetti E, Fabbi M, Ferraioli G, Prati P, Filice C, Sassera D, et al: Cat-scratch disease in Northern Italy: atypical clinical manifestations in humans and prevalence of Bartonella infection in cats. Eur J Clin Microbiol Infect Dis 32:531-534, 2013

10. Carithers HA: Cat-scratch disease. An overview based on a study of 1,200 patients. Am J Dis Child 139:1124-1133, 1985

11. Chomel BB: Cat-scratch disease. Rev Sci Tech 19:136-150, 2000

12. Dalton MJ, Robinson LE, Cooper J, Regnery RL, Olson JG, Childs JE: Use of Bartonella antigens for serologic diagnosis of cat-scratch disease at a national referral center. Arch Intern Med 155:1670-1676, 1995

13. Florin TA, Zaoutis TE, Zaoutis LB: Beyond cat scratch disease: widening spectrum of Bartonella henselae infection. Pediatrics 121:e1413-e1425, 2008

14. Giladi M, Kletter Y, Avidor B, Metzkor-Cotter E, Varon M, Golan Y, et al: Enzyme immunoassay for the diagnosis of cat-scratch disease defined by polymerase chain reaction. Clin Infect Dis 33:1852-1858, 2001

15. Hajjaji N, Hocqueloux L, Kerdraon R, Bret L: Bone infection in cat-scratch disease: a review of the literature. J Infect 54:417-421, 2007

16. Hamilton DH, Zangwill KM, Hadler JL, Cartter ML: Catscratch disease-Connecticut, 1992-1993. J Infect Dis 172:570-573, 1995

17. Hulzebos CV, Koetse HA, Kimpen JL, Wolfs TF: Vertebral osteomyelitis associated with cat-scratch disease. Clin Infect Dis 28:1310-1312, 1999

18. Hussain S, Rathore MH: Cat scratch disease with epidural 
extension while on antimicrobial treatment. Pediatr Neurosurg 43:164-166, 2007

19. Jackson LA, Perkins BA, Wenger JD: Cat scratch disease in the United States: an analysis of three national databases. Am J Public Health 83:1707-1711, 1993

20. Jacomo V, Kelly PJ, Raoult D: Natural history of Bartonella infections (an exception to Koch's postulate). Clin Diagn Lab Immunol 9:8-18, 2002

21. Knafl D, Lötsch F, Burgmann H, Goliasch G, Poeppl W, Ramharter M, et al: Hepatosplenic abscesses and osteomyelitis of the spine in an immunocompetent adult with cat scratch disease. Case Rep Infect Dis 2015:317260, 2015

22. Litwin CM, Martins TB, Hill HR: Immunologic response to Bartonella henselae as determined by enzyme immunoassay and Western blot analysis. Am J Clin Pathol 108:202-209, 1997

23. Massei F, Messina F, Talini I, Massimetti M, Palla G, Macchia $\mathrm{P}$, et al: Widening of the clinical spectrum of Bartonella henselae infection as recognized through serodiagnostics. Eur J Pediatr 159:416-419, 2000

24. Mazur-Melewska K, Mania A, Kemnitz P, Figlerowicz M, Służewski W: Cat-scratch disease: a wide spectrum of clinical pictures. Postepy Dermatol Alergol 32:216-220, 2015

25. Mirouse G, Journe A, Casabianca L, Moreau PE, Pannier S, Glorion C: Bartonella henselae osteoarthritis of the upper cervical spine in a 14-year-old boy. Orthop Traumatol Surg Res 101:519-522, 2015

26. Perkocha LA, Geaghan SM, Yen TS, Nishimura SL, Chan SP, Garcia-Kennedy R, et al: Clinical and pathological features of bacillary peliosis hepatis in association with human immunodeficiency virus infection. N Engl J Med 323:1581-1586, 1990

27. Regnery R, Martin M, Olson J: Naturally occurring "Rochalimaea henselae" infection in domestic cat. Lancet 340:557558,1992

28. Regnery RL, Olson JG, Perkins BA, Bibb W: Serological response to "Rochalimaea henselae" antigen in suspected catscratch disease. Lancet 339:1443-1445, 1992

29. Rohr A, Saettele MR, Patel SA, Lawrence CA, Lowe LH: Spectrum of radiological manifestations of paediatric catscratch disease. Pediatr Radiol 42:1380-1384, 2012

30. Ruess M, Sander A, Brandis M, Berner R: Portal vein and bone involvement in disseminated cat-scratch disease: report of 2 cases. Clin Infect Dis 31:818-821, 2000

31. Sander A, Berner R, Ruess M: Serodiagnosis of cat scratch disease: response to Bartonella henselae in children and a review of diagnostic methods. Eur J Clin Microbiol Infect Dis 20:392-401, 2001

32. Tasher D, Armarnik E, Mizrahi A, Liat BS, Constantini S, Grisaru-Soen G: Cat scratch disease with cervical vertebral osteomyelitis and spinal epidural abscess. Pediatr Infect Dis J 28:848-850, 2009

33. Verdon R, Geffray L, Collet T, Huet H, Parienti JJ, Debruyne M, et al: Vertebral osteomyelitis due to Bartonella henselae in adults: a report of 2 cases. Clin Infect Dis 35:e141-e144, 2002

34. Vermeulen MJ, Rutten GJ, Verhagen I, Peeters MF, van Dijken PJ: Transient paresis associated with cat-scratch disease: case report and literature review of vertebral osteomyelitis caused by Bartonella henselae. Pediatr Infect Dis J 25:11771181,2006

35. Woestyn S, Moreau M, Munting E, Bigaignon G, Delmée M: Osteomyelitis caused by Bartonella henselae genotype I in an immunocompetent adult woman. J Clin Microbiol 41:34303432, 2003

36. Zbinden R: Bartonella henselae-based indirect fluorescence assays are useful for diagnosis of cat scratch disease. J Clin Microbiol 36:3741-3742, 1998

\section{Disclosures}

The authors report no conflict of interest concerning the materials or methods used in this study or the findings specified in this paper.

\section{Author Contributions}

Conception and design: Akbari, Strahle. Acquisition of data: Akbari, Averill. Analysis and interpretation of data: Akbari, Averill. Drafting the article: Akbari. Critically revising the article: Akbari. Reviewed submitted version of manuscript: all authors. Approved the final version of the manuscript on behalf of all authors: Akbari. Statistical analysis: Akbari. Administrative/technical/material support: Strahle. Study supervision: Strahle.

\section{Correspondence}

Syed Hassan A. Akbari: St. Louis Children's Hospital, Washington University in St. Louis School of Medicine, St. Louis, MO. shakbari@wustl.edu. 